Revista de BIOLOGía TROPICAL

\title{
Observation frequency and seasonality of marine birds off the Pacific coast of Costa Rica
}

\author{
Bruce E. Young ${ }^{1} \&$ James R. Zook ${ }^{2}$ \\ 1. NatureServe, 4600 N. Fairfax Dr., 7th Floor, Arlington, VA 22203 USA; bruce_young@natureserve.org \\ 2. Apdo. 182-4200, Naranjo de Alajuela, Costa Rica; ebirdcr@gmail.com
}

Received 24-IV-2014. C Corrected 02-V-2015. Accepted 07-VI-2015.

\begin{abstract}
Although the Eastern Tropical Pacific is well known for its diverse fauna, the seabirds occurring off Costa Rica's Pacific coast have received little scientific attention. With seabirds now the fastest declining avian group, a better understanding of seabird diversity and abundance in this region is urgently needed. We report on observations of Costa Rica's Pacific seabirds made during 19 days of observations on 11 offshore trips from 2006-2010. We provide, for the first time, spatially and seasonally explicit information on the distribution of 41 species of seabirds (nine families). Species diversity is higher during the dry-wet season (36 species) and wet-dry season transitions (36 species) than during the dry season (19 species). The fauna included three threatened species (Pterodroma phaeopygia, Procellaria parkinsoni, and Puffinus creatopus) and two near-threatened species (Psueudobulweria rostrata and Thalasseus elegans), highlighting the importance of Costa Rican waters for the conservation of seabirds. Rev. Biol. Trop. 64 (Suppl. 1): S235-S248. Epub 2016 February 01.
\end{abstract}

Key words: Costa Rica, diversity, Eastern Tropical Pacific, seabirds, seasonality, threatened species.

The Eastern Tropical Pacific is an area of relatively high biological productivity that harbors a diverse and commercially valuable vertebrate fauna. Upwelling zones and a thermocline that lies close to the surface help explain the diversity and abundance of these animals (Jehl, 1974; Ballance, Pitman, \& Fiedler, 2006; Fiedler, \& Talley 2006). Seabirds are no exception, with approximately 42 species in ten families recorded off the Pacific coast of Costa Rica exclusive of the Isla del Coco area (Sandoval, \& Sánchez, 2013). Most of these species occur as seasonal, nonbreeding visitors, although 10-12 species breed on offshore islands (Stiles, 1984).

Recently conservationists have called attention to worldwide declines in seabirds due to fisheries bycatch, reduced prey bases caused by overfishing, introduced predators on breeding sites, climate change, and other threats (Furness, 2003; Grémillet, \& Boulinier, 2009;
BirdLife International, 2013). In fact, seabirds are now considered the most rapidly declining group of birds (Croxall, 2012; BirdLife International, 2013). Population trends and abundances of Costa Rican seabirds are largely unknown due to a lack of any monitoring program or regular observations. Despite the diversity of the Costa Rican seabird fauna, the country has no tradition of amateur seabird observations such as is found in many other coastal countries, particularly developed ones. Commercial whale watching expeditions, which can provide a platform for seabird observations, are limited to the near-shore area around Marino Ballena National Park in Costa Rica. Knowledge of the distribution and abundance of seabirds in the Pacific waters of Costa Rica is limited to sporadic expeditions that have taken place in the 1960s (King, 1974), early 1970s (Jehl, 1974), late 1970s and early 1980s (Stiles, 1984), and 1980s (Pitman, 1986). In the late 1990s and 
early 2000s, observations from oceanographic vessels took place in Costa Rican waters, but the research focus was on the Eastern Tropical Pacific broadly such that the data have not been disaggregated to describe the diversity and abundance of seabirds in any particular country (Ballance et al., 2006; Vilchis, Ballance, \& Fiedler, 2006). Additionally, seabird records from the vicinity of Isla del Coco were updated in the 2000s (Montoya, 2003; Easley, \& Montoya, 2006; Montoya, 2008).

To help fill this gap in knowledge about seabirds in Costa Rica, we present the results of observations made in 2006-2010 from vessels traveling as far as $380 \mathrm{~km}$ from the Pacific coast. Our goal was to explore and describe the relatively unknown seabird fauna and not to calculate precise density estimates of the species present. Trips were made as opportunities arose rather than to systematically sample seasonal abundance. Nevertheless, we were able to perform observations during seven months, in both rainy and dry seasons, and can report locations of observations relative to underwater features such as the continental slope.

\section{MATERIAL AND METHODS}

Study site: All observations took place off the northern, central, and southern Pacific coast of Costa Rica, within $380 \mathrm{~km}$ of shore (Fig. 1).

Observations: We observed seabirds from small vessels $<17 \mathrm{~m}$ in length, except for one trip made in a small cruise ship (Pacific Explorer, $56 \mathrm{~m}$ ), during 1-3 day trips (Table 1). The small size and slow speed (approximately $11 \mathrm{~km} / \mathrm{hr}$ ) of most of the vessels allowed for close observation of birds that crossed paths with the boat. With the exception of the Pacific Explorer trip which went to and from Isla del Coco (also known as Cocos Island), the vessels' tracks were set to sample marine environments both over the continental shelf (defined as depths $<200 \mathrm{~m}$ ), continental slope (200-800 m depth), and deep water (>800 m depth) in northern, central, and southern territorial waters of Costa Rica. The vessels traveled in straight transects, occasionally slowing or briefly altering course to allow time for accurate identification of passing birds (Fig. 1).

Birds were recorded as soon as they were identifiable, at any distance from the observer. The method precludes interspecific comparisons of abundance due to differences in detectability, but does allow within-species comparisons. Whenever possible, birds that were difficult to identify were photographed. From 5-9 observers participated in each trip, with JRZ joining all trips and therefore providing consistency in observations and records. We compiled observations for each daylight hour, recording our position with a GPS unit at hourly increments. We additionally made opportunistic observations at night for nocturnal species. The viewing conditions were remarkably consistent during all trips, with clear to partly cloudy skies, $<2 \mathrm{~m}$ swell, and less than $1.5 \mathrm{hr}$ of rain during the entire study. To provide a measure of seasonal occurrence, we calculated the percentage of all one-hour observation periods during which each species was recorded for the periods December-March (dry season), April-July (transition dry to wet season), and August- November (wet season). Although we observed other birds, we restrict

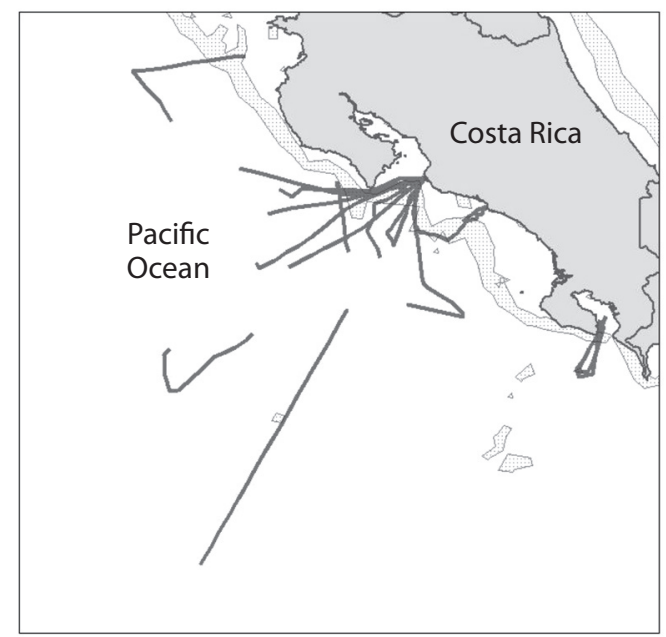

Fig. 1. Study area off the Pacific coast of Costa Rica. Dark gray lines indicate tracks where diurnal observations took place. Stippled areas represent $200-800 \mathrm{~m}$ bathymetry to indicate the location of the continental slope. 
TABLE 1

Details of observations

\begin{tabular}{cccc} 
Trip Number & Dates & Vessel & Region of Pacific Surveyed \\
1 & 19-20 Aug 2006 & Floating Bear & Central \\
2 & 8 Jan 2007 & Floating Bear & Central \\
3 & 4 Apr 2007 & C Tails & South \\
4 & 9-10 Apr 2007 & Floating Bear & Central \\
5 & 11-12 Jan 2008 & Floating Bear & Central \\
6 & 5 May 2008 & Rosa Maria $~$ & South \\
7 & 7 March 2009 & Reina del Sur & South \\
8 & 3-5 Apr 2009 & Floating Bear & North \\
9 & 26 Apr, 1 May 2009 & Pacific Explorer & Central \\
10 & September 18-20, 2009 & Floating Bear & Central \\
11 & November 14, 2010 & Floating Bear & Central \\
\hline
\end{tabular}

${ }^{1}$ Observations made en route to and from Isla del Coco.

this report to seabirds (families Procellariidae, Hydrobatidae, Phaethontidae, Fregatidae, Sulidae, Pelecanidae, Stercorariidae, Laridae, and the genus Phalaropus in the Scolopacidae). We were unable to collect data on sea surface temperature or other habitat variables. Taxonomy and sequence follow AOU (1998) and subsequent supplements through 2014 (Chesser et al., 2014).

\section{RESULTS}

We recorded 40 species of seabirds from nine families during 207 1-hr diurnal observation periods over 19 days during 11 trips (Table 2). One additional species, Creagrus furcatus, was detected only opportunistically at night.

The diversity of seabirds in our study area was lower in the dry season (19 species

TABLE 2

Seasonal, breeding, and conservation status of seabirds observed

\begin{tabular}{|c|c|c|c|c|}
\hline \multicolumn{5}{|c|}{ Percent of 1-hr observation periods recorded } \\
\hline Species $^{1}$ & Jan-Mar ${ }^{2}$ & Apr-Jul ${ }^{3}$ & Aug-Nov ${ }^{4}$ & Overall \\
\hline \multicolumn{5}{|l|}{ Procellariidae } \\
\hline Pterodroma phaeopygia (CR) & 0 & 1 & 0 & $<1$ \\
\hline Pterodroma rostrata $(\mathrm{NT})$ & 0 & 0 & 8 & 2 \\
\hline Procellaria parkinsoni (VU) & 0 & 8 & 2 & 4 \\
\hline Puffinus creatopus (VU) & 5 & 3 & 6 & 4 \\
\hline Puffinus pacificus (LC) & 63 & 52 & 24 & 45 \\
\hline Puffinus nativitatis (LC) & 0 & 1 & 0 & $<1$ \\
\hline Puffinus subalaris (LC) & 32 & 20 & 41 & 29 \\
\hline \multicolumn{5}{|l|}{ Hydrobatidae } \\
\hline Oceanites oceanicus (LC) & 3 & 1 & 16 & 6 \\
\hline Oceanodroma leucorhoa (LC) & 16 & 10 & 24 & 15 \\
\hline Oceanodroma castro (LC) & 3 & 0 & 3 & 1 \\
\hline Oceanodroma tethys (LC) & 0 & 8 & 41 & 16 \\
\hline Oceanodroma melania (LC) & 3 & 8 & 27 & 13 \\
\hline Oceanodroma markhami (DD) & 0 & 0 & 3 & 1 \\
\hline Oceanodroma microsoma (LC) & 5 & 4 & 6 & 5 \\
\hline
\end{tabular}


TABLE 2 (Continued)

\begin{tabular}{|c|c|c|c|c|}
\hline \multicolumn{5}{|c|}{ Percent of $1-\mathrm{hr}$ observation periods recorded } \\
\hline Species $^{1}$ & Jan-Mar² & Apr-Jul ${ }^{3}$ & Aug-Nov ${ }^{4}$ & Overall \\
\hline \multicolumn{5}{|l|}{ Phaethontidae } \\
\hline Phaethon aethereus (LC) & 0 & 5 & 11 & 6 \\
\hline \multicolumn{5}{|l|}{ Fregatidae } \\
\hline Fregata magnificens (LC) (b) & 34 & 33 & 40 & 35 \\
\hline \multicolumn{5}{|l|}{ Sulidae } \\
\hline Sula dactylatra (LC) (b) & 0 & 10 & 2 & 6 \\
\hline Sula granti (LC) (b) & 0 & 13 & 0 & 7 \\
\hline Sula nebouxii (LC) & 0 & 0 & 2 & $<1$ \\
\hline Sula leucogaster (LC) (b) & 66 & 71 & 68 & 69 \\
\hline Sula sula (LC) (b) & 0 & 22 & 10 & 14 \\
\hline \multicolumn{5}{|l|}{ Pelecanidae } \\
\hline Pelecanus occidentalis (LC) (b) & 11 & 4 & 3 & 5 \\
\hline \multicolumn{5}{|l|}{ Scolopacidae } \\
\hline Phalaropus lobatus (LC) & 18 & 11 & 30 & 18 \\
\hline Phalaropus fulicarius (LC) & 0 & 3 & 6 & 3 \\
\hline \multicolumn{5}{|l|}{ Stercorariidae } \\
\hline Stercorarius pomarinus (LC) & 34 & 23 & 11 & 21 \\
\hline Stercorarius parasiticus (LC) & 21 & 8 & 6 & 10 \\
\hline Stercorarius longicaudus (LC) & 0 & 1 & 2 & 1 \\
\hline \multicolumn{5}{|l|}{ Laridae } \\
\hline Creagrus furcatus (LC) & 0 & 2 & 0 & 1 \\
\hline Xema sabini (LC) & 0 & 2 & 24 & 8 \\
\hline Leucophaeus atricilla (LC) & 39 & 8 & 5 & 13 \\
\hline Leucophaeus pipixcan (LC) & 0 & 10 & 2 & 6 \\
\hline Anous stolidus (LC) (b) & 0 & 8 & 3 & 5 \\
\hline Gygis alba (LC) (b) & 0 & 6 & 2 & 3 \\
\hline Onychoprion fuscatus (LC) & 0 & 3 & 0 & 1 \\
\hline Onychoprion anaethetus (LC) (b) & 3 & 13 & 17 & 13 \\
\hline Sternula antillarum (LC) & 0 & 2 & 2 & 1 \\
\hline Chlidonias niger (LC) & 68 & 53 & 30 & 49 \\
\hline Sterna hirundo (LC) & 0 & 5 & 3 & 3 \\
\hline Thalasseus maximus (LC) & 8 & 6 & 3 & 5 \\
\hline Thalasseus sandvicensis (LC) & 8 & 4 & 2 & 4 \\
\hline Thalasseus elegans (NT) & 0 & 0 & 6 & 2 \\
\hline Species recorded & 19 & 36 & 36 & 41 \\
\hline
\end{tabular}

1. IUCN status (IUCN, 2013) $(\mathrm{LC})=$ Least Concern, $(\mathrm{CR})=$ Critically Endangered, $(\mathrm{VU})=$ Vulnerable, $(\mathrm{NT})=\mathrm{Near}$ Threatened, (DD) $=$ Data Deficient. (b) =breeds in Costa Rica.

2. No observations were made during December. Sample size: 38 1-hr observation periods.

3. Sample size: 106 1-hr observation periods.

4. Sample size: 63 1-hr observation periods.

recorded) than in either the dry-wet transition or wet seasons (36 species recorded in each season). The most frequently detected species was Sula leucogaster (present in $69 \%$ of $1-\mathrm{hr}$ observation periods), followed by
Chlidonias niger (49\%) and Puffinus pacificus (45\%). The rarest species were Pterodroma phaeopygia, and Sula nebouxii, each of which was represented by a single individual in our observations. Three species are listed in a 
Threatened Red List category and two in a Near-Threatened one (Table 2).

\section{SPECIES ACOUNTS}

Pterodroma phaeopygia (Salvin, 1876) (Galápagos Petrel): We observed a sole individual of this Critically Endangered species, which breeds on the Galápagos Islands. At 05:56 on 1 May 2009, on our return from Isla del Coco (6 $0^{\circ} 39^{\prime} 33^{\prime \prime} \mathrm{N}-86^{\circ} 24^{\prime} 26^{\prime \prime} \mathrm{W}$ ) (Fig. 2 ), an individual approached the vessel on a roughly parallel course about $100 \mathrm{~m}$ away and was in sight for less than a minute. Two $S$. leucogaster were the only other birds visible at the time. Flight was mostly gliding with occasional flaps at a height of 1-3 $\mathrm{m}$ above a calm sea surface. The identification was confirmed by photos (Jones, \& Komar, 2009a). This species has been reported regularly over offshore waters of Middle America (Spear, Ainley, Nur, \& Howell, 1995).

Pterodroma rostrata (Peale, 1848) (Tahiti Petrel): This distinctive species occurred as scattered individuals well beyond the continental slope during our only September trip, during which we documented its presence photographically (Jones, \& Komar, 2010). One year later, also in September, the species was reported for first time in Panama (Jones, \& Komar, 2011). The species disperses widely from its breeding areas, the closest of which are in the Society Islands in the South Pacific, over $7000 \mathrm{~km}$ away (Howell, 2012).

Procellaria parkinsoni Gray, 1862 (Parkinson's Petrel): This species has been reported off the Pacific coast of Central America (Jehl, 1974; Stiles, \& Skutch, 1989; Pitman, \& Balance, 1992). We observed several birds on 4 April 2009 well offshore (Fig. 2) in the vicinity of the Costa Rica Dome, a seasonal oceanographic feature that occurs off of the province of Guanacaste during the dry season and is characterized by a shallow thermocline and significant upwelling (Fiedler, 2002;
Ballance et al., 2006). Although most Central American records of this species are from April and May (Stiles, \& Skutch, 1989), we also observed it in September 2009 well south of the Nicoya Peninsula.

Puffinus creatopus (Coues, 1864) (Pinkfooted Shearwater): We observed this species mostly as single individuals in deep water beyond the continental slope on five separate trips. Although the species was known previously only from the vicinity of Isla del Coco (Stiles, \& Skutch, 1989; Easley, \& Montoya, 2006; Montoya, 2008), we observed it off the north, central, and southern coasts of Costa Rica suggesting the species is a regular, widespread visitor. The species also occurred nearly year round, with observations in January, March, April, September, and November, in contrast to previous observations (Stiles, \& Skutch, 1989).

Puffinus pacificus (Gmelin, 1789) (Wedge-tailed Shearwater): This was the most regularly-seen tubenose species, especially for the period January to July (Table 2). Birds were seen in flight and on the water as individuals or in loose flocks (the highest hourly count was 228). Occasional dark or intermediate morph birds were seen but most were the light morph. This species appeared to be most abundant over the continental slope and in deeper water just beyond (Fig. 2), where they are likely dispersing from Hawaii (Howell, 2012).

Puffinus nativitatis Streets, 1877 (Christmas Shearwater): We observed two individuals, on 3 April 2009 in deep water $35 \mathrm{~km}$ from the Nicoya Peninsula. Both birds were resting on the water with different groups of $P$. pacificus. This species is a regular non-breeding visitor off Mexico and Central America, where it disperses from breeding areas in the south Pacific islands including Easter Island (Carboneras, 1992; Spear, \& Ainley, 1999b; Howell, 2012), it is not surprising that this shearwater at least occasionally wanders to Costa Rica. 


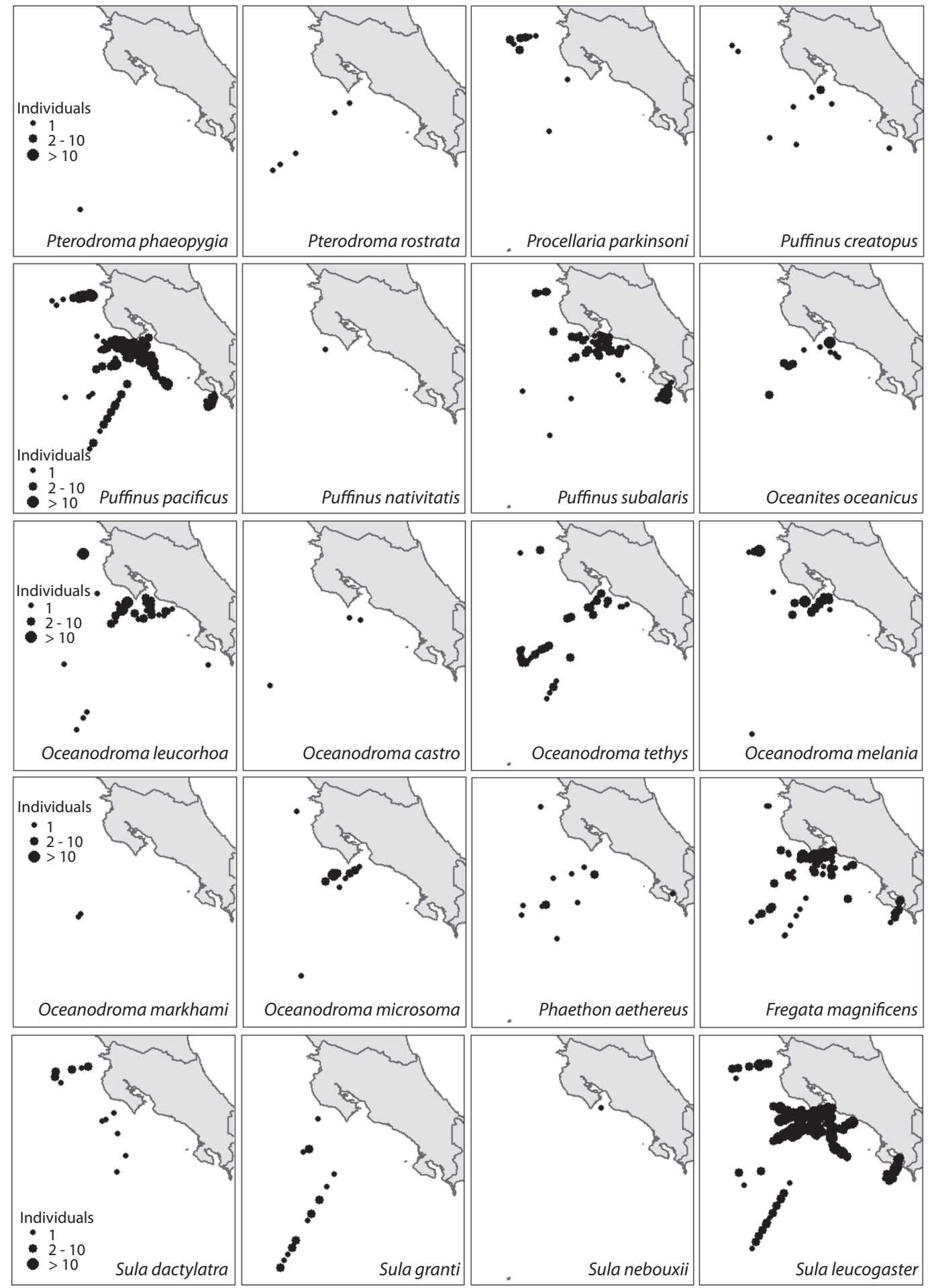

Fig. 2. Locations and relative abundances of seabirds observed off the Pacific coast of Costa Rica, 2006-2010. 


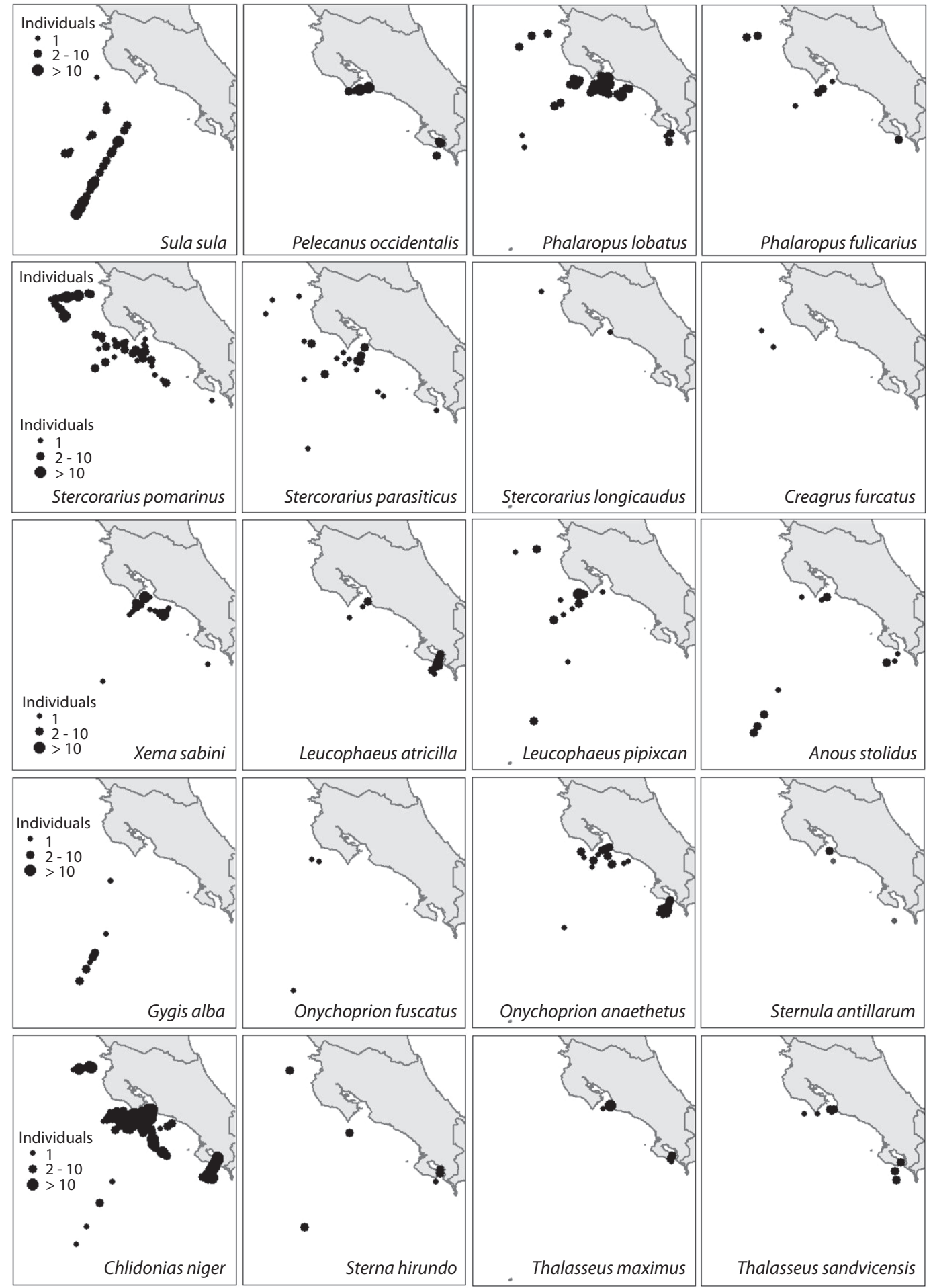

Fig. 2. (Continued). Locations and relative abundances of seabirds observed off the Pacific coast of Costa Rica, 20062010. 


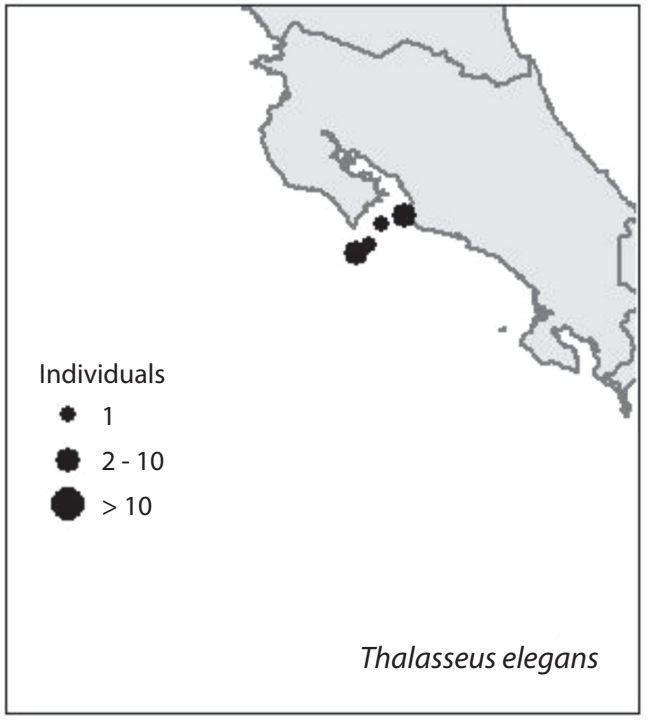

Fig. 2. (Continued). Locations and relative abundances of seabirds observed off the Pacific coast of Costa Rica, 2006-2010.

Puffinus subalaris Ridgway, 1897 (Galapagos Shearwater): We observed this species regularly, year round. Observations appeared to be most frequent over the continental slope, with fewer individuals appearing over deeper or shallower water (Fig. 2). Most often seen as pairs or individuals, this was one of the few species that would customarily follow the boat, often for periods of up to one hour. We did not distinguish between "white-winged" and "black-winged" types, which may represent separate species (Howell, 2012).

Oceanites oceanicus (Kuhl, 1820) (Wilson's Storm-Petrel): We recorded this panoceanic storm-petrel most frequently during August and September trips. Although the species usually occurred as single individuals, we documented one aggregation of 81 individuals on 20 August 2006 in the mouth of the Gulf of Nicoya. We do not know whether birds off Costa Rica are from Antarctic (nominate oceanicus) or South American (chilensis) populations.
Oceanodroma leucorhoa (Vieillot, 1818) (Leach's Storm-Petrel): This species was regularly seen over the continental slope and in deeper water (Fig. 2). Although the species has been reported as a seasonal visitor to Costa Rica (Stiles, \& Skutch, 1989), we observed it year round, on nine of the 11 trips. We observed birds that exhibited a full range of rump patterns from white to intermediate to dark, as has been noted in California (Howell, McGrath, Hunefeld, \& Feenstra, 2010), but the data presented here are for all morphs combined.

Oceanodroma castro (Harcourt, 1851) (Band-rumped Storm-Petrel): We observed only three individuals, one in January 2007 and two in September 2009, all in deep water. Other Costa Rican reports are from the months of May and June (Stiles, \& Skutch, 1989), and one Panama report is from September (Jones, \& Komar, 2011). These observations suggest that there may be little seasonality to when the species visits Costa Rican waters from its Galapagos breeding areas (Howell, 2012). Unfortunately, we were unable to obtain photographic evidence of this confusing species, which still needs unequivocal evidence of its occurrence in Costa Rica.

Oceanodroma tethys (Bonaparte, 1852) (Wedge-rumped Storm-Petrel): This species is likely a seasonal visitor to Costa Rica. We detected it most regularly in August and September, and less frequently in April and May (Table 2). Although we did not distinguish between the subspecies, based on observations in Mexico and the Gulf of Panama, the South American kelsalli is the most likely in Costa Rican waters within $500 \mathrm{~km}$ of the coast (Spear, \& Ainley, 2007; Howell, 2012).

\section{Oceanodroma melania (Bonaparte, 1854)} (Black Storm-Petrel): Although we observed this large storm-petrel nearly year-round, it was most regular in April, when concentrations of up to 72 individuals were encountered. The species appears to prefer inshore waters along the continental slope (Spear, \& Ainley, 2007). 
Oceanodroma markhami (Salvin, 1883) (Markham's Storm-Petrel): On 19 September 2009 we observed two individuals, the first documented records for Costa Rica. As has been reported for Central America (Spear, \& Ainley, 2007; Howell, 2012), the storm-petrels were well offshore, approximately $240 \mathrm{~km}$ from the nearest land (Fig. 2). We were able to distinguish $O$ markhami from $O$. melania only by examining photographs taken of birds that closely approached our observation vessels. Several other birds were suspected of being this species but we were unable to photograph them. Due to the identification challenge, the species may be more common in Costa Rica than the paucity of records indicates (Stiles, \& Skutch, 1989).

Oceanodroma microsoma (Coues, 1864) (Least Storm-Petrel): We observed this species infrequently, during April, August, and September either over the continental slope or farther offshore (Fig. 2).

Phaethon aethereus Linnaeus, 1758 (Red-billed Tropicbird): We regularly observed this species well offshore, always as single birds, during both the dry-wet and wet-dry season transitions (Fig. 2, Table 2). Of the 12 individuals we saw, only 2 were adults.

Fregata magnificens Matthews, 1914 (Magnificent Frigatebird): This species is widespread, occurring along the length of the coast and continuously well offshore (Fig. 2). It was most abundant near Isla Cabo Blanco, located off the southern tip of the Nicoya Peninsula, where the species breeds.

Sula dactylatra Lesson, 1831 (Masked Booby): We regularly observed this species well offshore during both the dry-wet and wetdry season transitions. The species was seen as individuals or adult/immature pairs.

Sula granti Rothschild, 1902 (Nazca Booby): Our observations of this species were restricted to areas well beyond the continental slope during April and May (Fig. 2, Table 2). This species, as well as the previous one, would characteristically approach our vessel and circle us once or twice before continuing on.

Sula nebouxii Milne-Edwards, 1882 (Blue-footed Booby): This species is primarily a coastal species that is occasionally found further offshore. We observed a single individual of this species in the mouth of the Gulf of Nicoya on 20 September 2009 together with hundreds of $S$. leucogaster, F. magnificens, Pelecanus occidentalis, and other seabirds that were attracted to a fishing boat dumping bycatch (Fig. 2). This is the only Sula species we observed that does not breed in Costa Rica, although it does breed as close as Panama Bay (Ridgley, \& Gwynne, 1992) and possibly in the Gulf of Fonseca (Howell, \& Webb, 1995). The scarcity of records in Costa Rica suggests that individuals from these breeding populations do not disperse widely.

Sula leucogaster (Boddaert, 1783) (Brown Booby): Together with F. magnificens, $S$. leucogaster was one of the most frequently detected species, occurring year round and at all distances from shore (Fig. 2, Table 2). We observed hundreds of individuals apparently nesting on Isla Cabo Blanco, and frequently saw groups of birds flying to and from the island. Occasional individuals of the race $S$. $l$. brewsteri were observed.

Sula sula (Linnaeus, 1766) (Red-footed Booby): We regularly detected this species well offshore in all seasons except the dry season (Fig. 2, Table 2). In early May 2009, the species was particularly common with up to 131 individuals counted during one hour of observations. This was at our closest approach to Isla del Coco where the species breeds (AOU, 1998). All birds were of the typical all-brown Pacific morph except for one white bird and two brown birds with white tails, all of which were observed on the trip en route to and from Isla del Coco. 
Pelecanus occidentalis Linnaeus, 1766 (Brown Pelican): Pelicans favor the coasts, where they occur year round (Table 2). Only once, in May 2009 off the Osa Peninsula where deep water is close to shore, did we observe this species beyond the continental slope (Fig. 2).

Phalaropus lobatus (Linnaeus, 1758) (Red-necked Phalarope): We observed small groups of this species on all trips with small vessels where proximity to the water aided detection of this small pelagic shorebird (Table 2). Although our results suggest the species inhabits Costa Rican waters year-round, we note that we made no observations in July when the species nests in northern North America (AOU, 1998). We observed the species over the continental shelf as well as further offshore (Fig. 2).

Phalaropus fulicarius (Linnaeus, 1758) (Red Phalarope): This species was detected in similar areas but less frequently than its congener (Fig. 2). Its absence during the dry season (Table 2) suggests that the species may only occur regularly in Costa Rica as a passage migrant.

Stercorarius pomarinus (Temminck, 1815) (Pomarine Jaeger): This was the most frequently observed jaeger, occurring yearround over the continental shelf and deeper water (Fig. 2, Table 2).

Stercorarius parasiticus (Linnaeus, 1758) (Parasitic Jaeger): Although less commonly observed than $S$. pomarinus, this species occurred in the same areas and was equally aseasonal (Fig. 2, Table 2).

Stercorarius longicaudus Vieillot, 1819 (Long-tailed Jaeger): We recorded this species twice, on 4 April 2009 and 14 November 2010. Both individuals (immatures), which we identified from photographs, occurred over the continental slope (Fig. 2).
Creagrus furcatus (Néboux, 1842) (Swallow-tailed Gull): We observed two individuals of this species, both attracted to our boat at night and well offshore (Fig. 1). As we have documented elsewhere, some individuals of this species regularly disperse to Costa Rican waters from breeding colonies in the Galapagos Islands from late March to early May (Young et al., 2010).

Xema sabini (Sabine, 1819) (Sabine's Gull): We observed this species most frequently from August to November, although we also observed single individuals in late April and early May (Table 2). The species occurred over the continental slope or somewhat further out, but rarely far offshore (Fig. 2).

Leucophaeus atricilla (Linnaeus, 1758) (Laughing Gull): This species was abundant year-round in coastal waters out to the continental slope.

Leucophaeus pipixcan (Wagler, 1831) (Franklin's Gull): This species passes through Costa Rica during southward and northward migrations from its North American breeding areas (Stiles, \& Skutch 1989). Although the species is known to migrate up the Golfo de Nicoya (Stiles, \& Skutch 1989), we observed it more frequently well out at sea (Fig. 2), suggesting the species follows multiple routes during its passage through Costa Rica. This species is known to migrate offshore between South and Central America (Howell, \& Dunn, 2007).

Anous stolidus (Linnaeus, 1758) (Brown Noddy): We observed this species infrequently at almost any distance from shore (Fig. 2). It was absent during the dry season (Table 2).

Gygis alba (Sparrman, 1786) (White Tern): This species breeds on Isla del Coco, approaching the mainland only rarely (Stiles, \& Skutch 1989). Our observations of the species were all made well offshore (Fig. 2) with all but one of our sightings made during the voyages to and from Isla del Coco. 
Onychoprion fuscatus (Linnaeus, 1766) (Sooty Tern): We observed three individuals of this species, all well offshore during April and May (Fig. 2, Table 2).

Onychoprion anaethetus (Scopoli, 1786) (Bridled Tern): We observed scattered individuals of this species year-round and generally fairly close to shore (Fig. 2, Table 2).

Sternula antillarum Lesson, 1847 (Least Tern): This species is typically observed close to shore (Stiles, \& Skutch 1989), but we observed three individuals over the continental slope on three separate trips that took place in April and August.

Chlidonias niger (Linnaeus, 1758) (Black Tern): Although this tern does not breed closer to the study area than North America (AOU, 1998), the species occurs in Costa Rica yearround. It was one of the most frequently detected species in our observations (Table 2), usually occurring in flocks with up to 132 individuals counted in an hour. The abundance of this species declined well offshore (Fig. 2).

Sterna hirundo Linnaeus, 1758 (Common Tern): We observed a few individuals of this species during April, May, and November, when it can appear almost any distance from shore (Fig. 2).

Thalasseus maximus (Boddaert, 1783) (Royal Tern): This species is abundant yearround close to shore (Stiles, \& Skutch, 1989), and was occasionally observed in deeper water (Fig. 2).

Thalasseus sandvicensis (Latham, 1787) (Sandwich Tern): Similar to T. maximus, this species is primarily a coastal species that is occasionally found further offshore (Fig. 2), possibly during migrations. We observed the species during March, April, and September.

Thalasseus elegans (Gambel, 1849) (Elegant Tern): As with the other Thalasseaus terns, this is primarily a coastal species that we observed at sea in September and November (Table 2).

\section{DISCUSSION}

Our observations emphasize the diversity of seabirds that occur off the Pacific coast of Costa Rica. Of the 42 species reported from the area prior to the initiation of our study (Stiles, \& Skutch, 1989; Sandoval, \& Sánchez, 2013), we recorded 38. The lower diversity we recorded during dry season months relative to other seasons in Costa Rica matches that reported previously for Gulf of Panama (Loftin, 1991). Our observations added two species ( $P$. phaeopygia, $P$. nativitatis) to the list of birds known from Costa Rica (Jones, \& Komar, 2009a, 2009b), and provided the first photographic evidence for occurrence in Costa Rica of an additional two species $(O$. markhami, and P. creatopus; Jones, \& Komar, $2009 \mathrm{~b}, 2011)$. Due to the paucity of previous observations in our study area, we suggest that these species have been overlooked previously (but see Pitman, 1986).

Four species, Puffinus tenuirostris, Puffinus griseus, Puffinus opisthomelas, and Stercorarius maccormicki, have been reported previously in Pacific waters of Costa Rica outside of the Isla del Coco area but not during our study. Puffinus tenuirostris and P. opisthomelas appear to be accidental to Costa Rica, known from few sightings (Stiles, \& Skutch, 1989) and therefore not surprisingly missed during our study. We did have one sighting, on 18 September 2009, of a small, black and white shearwater that could have been $P$. puffinus but we were unable to photograph it, and therefore could not confirm identification. Stiles and Skutch (1989) reported several sightings of $S$. maccormicki along the Pacific coast of Costa Rica.

Another previously reported species that we did not observe was Puffinus griseus. Although reported as common to abundant from May to October (Stiles, \& Smith, 1977; Stiles, \& Skutch, 1989), we failed to observe this 
species during any of the seven days of observations across three years of the study in this time period. Costa Rican birds likely originate from New Zealand breeding colonies (Spear, \& Ainley, 1999a), which undertake spectacular migrations of over $60000 \mathrm{~km}$ covering a wide area of the Pacific Ocean (Shaffer et al., 2006). Tracks of data-logged birds in 2005 suggest that the species may not regularly migrate near Costa Rica (Shaffer et al., 2006). Also, the species has declined widely in the Pacific (Scofield, \& Christie, 2002; Scott,Scofield, Hunter, \& Fletcher, 2008). Other authors note that this species tends to avoid warm, windless waters and generally considered it scarce off tropical Mexico and Central America (Pitman, 1986; Howell, 2012).

With more observations, additional species will surely be recorded from the Pacific waters of Costa Rica. For example, Pterodroma externa is known to be widespread in the Eastern Tropical Pacific (Ballance et al. 2006) and could be expected to wander into Costa Rican waters from time to time. Subsequent to our study, the albatross Phoebastria irrorata was photographed south of the Nicoya Peninsula and the tern Larosterna inca was photographed in the Gulf of Nicoya (Sandoval, \& Sánchez, 2013).

We recorded the presence of three threatened procellariids and two near-threatened species (a procellariid and a tern) in the Pacific waters of Costa Rica (Table 2). None of the threatened species breed in Costa Rica and, with the exception of $P$. creatopus, these species were absent from January to March. With these species occurring in territorial waters, Costa Rica has partial responsibility for their conservation. During our observation periods, the only potential localized threats to these species that we could discern were occasional artisanal long-line fishing operations. Monitoring of seabird populations, a conservation measure first proposed by Stiles (1984), has still not been implemented. Our results, covering the extent of the Costa Rican Pacific coast and providing quantitative, spatially explicit relative abundance data, can serve as valuable background information for the establishment of such a program.

\section{ACKNOWLEDGMENTS}

We thank Paul Murgatroyd for inviting us to perform observations aboard the Floating Bear, the many observers and photographers that accompanied us on the cruises, the ship captains for returning us safely to port, and four anonymous reviewers for comments that significantly improved the quality of the manuscript.

\section{RESUMEN}

El Pacifico Tropical Oriental es bien conocido por su diversa fauna; sin embargo, las aves marinas que se encuentran frente a la costa pacífica de Costa Rica no han recibido mucha atención científica. Reconociendo que las aves marinas representan el grupo de aves que más rápidamente está disminuyendo, se requiere urgentemente un mejor conocimiento de la diversidad y abundancia de las aves marinas en esta región. Reportamos observaciones de aves marinas del Pacifico de Costa Rica hechas durante 19 días de observación en 11 giras mar afuera entre el 2006 y el 2010. Proveemos, por primera vez, información espacialmente y estacionalmente sobre la distribución de 41 especies de aves marinas (nueve familias). La diversidad de especies es mayor durante las transiciones entre las estaciones seca-húmeda (36 especies) y húmeda-seca (36 especies) que durante la estación seca (19 especies). La avifauna incluye tres especies amenazadas (Pterodroma phaeopygia, Procellaria parkinsoni y Puffinus creatopus) y dos especies casi amenazadas (Psueudobulweria rostrata y Thalasseus elegans), lo que resalta la importancia de las aguas costarricenses para la conservación de las aves marinas.

Palabras clave: Costa Rica, diversidas, Pacific Tropical Este, aves marinas, estacionalidad, especies amenazadas.

\section{REFERENCES}

American Ornithologists' Union (AOU). (1998). Check-list of North American Birds (7th ed.). Washington, DC: American Ornithologists' Union.

Ballance, L. T., Pitman, R. L., \& Fiedler, P. C. (2006). Oceanographic influences on seabirds and cetaceans of the eastern tropical Pacific: A review. Progress in Oceanography, 69, 360-390.

BirdLife International. (2013). State of the World's Birds: Indicators for our Changing World. Cambridge, UK: BirdLife International. 
Carboneras, C. (1992). Family Procellariidae (petrels and shearwaters). In J. del Hoyo, A. Elliott, \& J. Sargatal (Eds.), Handbook of the Birds of the World. Vol. 1 (pp. 216-257). Barcelona, Spain: Lynx Editions.

Chesser, T. R., Banks, R. C., Cicero, C., Dunn, J. L., Kratter, A. W., Lovette, I. J., Navarro-Sigüenza, A. G., Rasmussen, P. C., Remsen, J. V., Jr., Rising, J. D., Stotz, D. F., \& Winker, K. (2014). Fifty-fifth supplement to the American Ornithologists' Union checkList of North American birds. Auk, 131, CSi-CSxv. doi: 10.1642/AUK-14-124.

Croxall, J. P. (2012). Seabird conservation status, threats and priority actions: a global assessment. Bird Conservation International, 22, 1-34.

Easley, K., \& Montoya, M. (2006). Observaciones ornitológicas en la Isla del Coco, Costa Rica (Mayo 2006). Zeledonia, 10, 31-41.

Fiedler, P. C. (2002). The annual cycle and biological effects of the Costa Rica dome. Deep-Sea Research I, 49, 321-338.

Fiedler, P. C., \& Talley, L. D. (2006). Hydrography of the eastern tropical Pacific: a review. Progress in Oceanography, 69, 143-180.

Furness, R. W. (2003). Impacts of fisheries on seabird communities. Scientia Marina, 67(2), 33-45.

Grémillet, D., \& Boulinier, T. (2009). Spatial ecology and conservation of seabirds facing global climate change: A review. Marine Ecology Progress Series, 391, 121-137.

Howell, S. N. G. (2012). Petrels, albatrosses, and stormpetrels of North America. New Jersey, NJ: Princeton University Press.

Howell, S. N. G., \& Dunn, J. (2007). A Reference Guide to Gulls of the Americas. New York, NY: Houghton Mifflin Harcourt.

Howell, S. N. G., \& Webb, S. (1995). The Birds of Mexico and Northern Central America. New York, NY: Oxford University Press.

Howell, S. N. G., McGrath, T., Hunefeld, W. T., \& Feenstra, J. S. (2010). Occurrence and identification of the Leach's Storm-Petrel (Oceanodroma leucorhoa) complex off southern California. North American Birds, 63, 540-549.

International Union for the Conservation of Nature (IUCN). (2013). IUCN Red List of Threatened Species. Version 2013.2. Gland, Switzerland: IUCN. Retrieved from http://www.iucnredlist.org

Jehl, J. R., Jr. (1974). The near-shore avifauna of the Middle American west coast. Auk, 91, 681-699.

Jones, H. L., \& Komar, O. (2009a). Central America (in The Regional Reports: Spring Migration, March through May 2009). North American Birds, 63, 513-518.
Jones, H. L., \& Komar, O. (2009b). Central America (in The Regional Reports: Fall Migration, August through November 2009). North American Birds, 64, 164-168.

Jones, H. L., \& Komar, O. (2010). Central America (in The Regional Reports: Fall Migration, August through November 2009). North American Birds, 64, 164-169.

Jones, H. L., \& Komar, O. (2011). Central America (in The Regional Reports: Fall Migration, August through November 2010). North American Birds, 65, 174-180.

King, W. B. (Ed.). (1974). Pelagic studies of seabirds in the central and eastern Pacific Ocean. Smithsonian Contributions to Zoology, 158, 1-277.

Loftin, H. (1991). An annual cycle of pelagic birds in the Gulf of Panama. Ornitología Neotropical, 2, 85-94.

Montoya, M. (2003). Aves de la Isla del Coco. Lista de especies. Zeledonia, 7, 29-37.

Montoya, M. (2008). Aves marinas de la Isla del Coco, Costa Rica, y su conservación. Revista de Biología Tropical, 56(Supplement 2), 133-149.

Pitman, R. L. (1986). Atlas of seabird distribution and relative abundance in the Eastern Tropical Pacific. (Report LJ-86-02C). Maryland, USA: National Marine Fisheries Service Administration.

Pitman, R. L., \& Balance, L. T. (1992). Parkinson's Petrel distribution and foraging ecology in the eastern Pacific: aspects of an exclusive feeding relationship with dolphins. Condor, 94, 825-835.

Ridgely, R. S., \& Gwynne, J. A. (1992). A Guide to the Birds of Panama: With Costa Rica, Nicaragua, and Honduras. New Jersey, NJ: Princeton University Press.

Sandoval, L., \& Sánchez, C. (2013). Lista de aves de Costa Rica: Décima sexta actualización. San José, Costa Rica: Unión de Ornitólogos de Costa Rica.

Scofield, R. P., \& Christie, D. (2002). Beach patrol records indicate a substantial decline in sooty shearwater (Puffinus griseus) numbers. Notornis, 49, 158-165.

Scott, D., Scofield, P., Hunter, C., \& Fletcher, D. (2008). Decline of sooty shearwaters, Puffinus griseus, on The Snares, New Zealand. Papers and Proceedings of the Royal Society of Tasmania, 142, 185-196.

Shaffer, S. A., Tremblay, Y., Weimerskirch, H., Scott, D., Thompson, D. R., Sagar, P. M., Moller, H. Taylor, G. A., Foley, D. G., Block, B. A., \& Costa, D. P. (2006). Migratory shearwaters integrate oceanic resources across the Pacific Ocean in an endless summer. Proceedings of the National Academy of Sciences of the United States of America, 103, 12799-12802. 
Spear, L. B., \& Ainley, D. G. (1999a). Migration routes of sooty shearwaters in the Pacific Ocean. Condor, 101, 205-218.

Spear, L. B., \& Ainley, D. G. (1999b). Seabirds of the Panama Bight. Waterbirds, 22, 175-198.

Spear, L. B., \& Ainley, D. G. (2007). Storm-Petrels of the Eastern Pacific Ocean: species assembly and diversity along marine habitat gradients. Ornithological Monographs, 62, 1-77.

Spear, L. B., Ainley, D. G., Nur, N., \& Howell, S. N. G. 1995. Population size and factors affecting at-sea distributions of four endangered procellariids in the tropical Pacific. Condor, 97, 613-638.

Stiles, F. G. (1984). Status and conservation of seabirds in Costa Rican waters. In J. P. Croxall, P. G. H. Evans, \& R. W. Schreiber (Eds.), Status and Conservation of the World's Seabirds (pp. 223-229). Cambridge, UK: ICBP.

Stiles, F. G., \& Skutch, A. F. (1989). A Guide to the Birds of Costa Rica. Ithaca, New York, NY: Cornell University Press.

Stiles, F. G., \& Smith, S. M. (1977). New information on Costa Rican waterbirds. Condor, 79, 91-97.

Vilchis, L. I., Ballance, L. T., \& Fiedler, P. C. (2006). Pelagic habitat of seabirds in the eastern tropical Pacific: Effects of foraging ecology on habitat selection. Marine Ecology Progress Series, 315, 279-292.

Young, B. E., Easley, K., Garrigues, R., Mactavish, B., Murgatroyd, P., \& Zook, J. R. (2010). Swallow-tailed gull Creagrus furcatus in Costa Rica. Cotinga, 32, 24-26. 